\title{
Mind Mapping Technique With Think Pair Share Strategy Towards Writing Ability In Descriptive Text
}

\section{Eko Erfiyanti1 ${ }^{*}$, Mustaji $^{2}$, Retno Danu R ${ }^{3}$}

1,3 Teknologi Pendidikan, Pascasarjana, Universitas PGRI Adi Buana Surabaya-

2 Teknologi Pendidikan, Pascasarjana Universitas Negeri Surabaya-

A R T I C L E I N F O

Article history:

Received 01 December 2018

Received in revised

form

31 December 2018

Accepted 15 January 2019

Available online 25

February 2019

Keywords:

Mind mapping, writing, descriptive text

\section{A B S T R A C T}

This research is applied to tenth graders of SMKN 1 Pungging to investigate the influence of teaching writing descriptive text ability using mind mapping technique with think pair share strategy. This population of this research is the tent graders that consist of 620 students which is taken 64 students as the sample. There are two classes; they are X TKJ 1 which is applied by teaching writing descriptive text using mapping technique with think pair share strategy and $\mathrm{X}$ TKJ 2 which is taught writing descriptive text by conventional technique. However, both of the groups were taught the same materials based on the curriculum. This study used pretest-posttest nonequivalent control group design for experimental and control groups. The pre test and post test were administered not only to the experimental group but also the control group. The pre test is as starting point to verify the condition of both groups. Finally, at the end of the treatment, the experimental group and the control group received a post test; the result of the post test was to define the significance difference between the experimental group and the control group. The result is there is significance difference between the classes which is taught writing descriptive text using mind mapping technique with think pair share strategy and which is taught writing descriptive by the conventional technique. The result calculated by SPSS 20.0; it is a computer program statistical calculation and the result is further discussed in Hypothesis Testing. It is approved that the mean of posttest of experimental group is increased from 58.28 to 80.16 . It can be noticed that the mean of the post-test of experimental is 21.72 higher than the mean of post-test of control group. 


\section{Introduction}

There are four skills of language namely; listening, speaking, reading and writing. (Nunan, 1991) states that writing is clearly a complex process and competent writing is accepted as the last language skill to be acquired.

Writing is a productive language skill as speaking skill. The purpose of writing skill is to share information from spoken language into written language. It needs a great thinking to produce writing begin from getting main idea, planning, and revising procedure. To achieve it comprehensively, it requires the specific skill which not all the people could develop it. From previous elaboration it can be concluded that writing is the act of expressing ideas or thoughts in communication using graphic symbols which are arranged based on certain rules and conventions.

Raimes (1993) indicates that writing is an integral part of communication when the other person is not right there in front of us, listening to our words and looking at our gestures and facial expressions. Writing is considered as the most difficult skill. The difficulty lies not only in generating and organizing idea, but also in translating these ideas to readable text (Richards and Renandya, 2002) affirm that writing is not a simple skill to transfer a spoken language but it requires particular aspects to transmit a message into a piece of paper clearly. In the same line, (Brown H. D., 2001) defines that writing is a language skill; the graphic representation of spoken language and that written performance is much like oral performance, the only difference lying in graphic instead of auditory signal.

The students also have to know about the structure of the English writing and the choice of words that are used in the writing. (Richards and Renandya, 2002, p. 303) argue that writing is difficult skill for second language learner to master. The difficulty lies not only in generating and organizing idea, but also in translating this idea into readable text

Descriptive is the type of the text in Senior High School, especially for tenth graders. They have to be mastered in producing descriptive text both of describe people, thing, and place. Regrettably, they are difficult enough to be learned by the students, although the students can use simple present, preposition of place and adjective clause in writing descriptive text.

The result of students' writing descriptive text of SMKN 1 Pungging is under the minimum criteria of SMKN 1 Pungging which is 75 . The students are not able to write the descriptive texts perfectly. The score in writing descriptive is at the average 6 and some of them got lower than 6. It seems that problem happened in this school was caused by inappropriate teaching strategy used by the teacher. In teaching and learning process, the teacher still used conventional method which was more on reading and speaking than writing and the teacher just focused on textbook.

The student needs to learn writing in order to be able to express their ideas, thought, and feeling in the best possible ways in written form. The conveying of a message to the reader, therefore the ideas themselves should arguably be seen as the most important aspect of the writing. Furthermore, (Ur, 2003) the students need also to pay attention to formal aspect: punctuation, as well as acceptable grammar and careful selection of vocabulary. In term of difficulty in organizing idea, (Rustler, 2012, p. 29) states that a Mind Maps that can help students to form their ideas, associations and impression in ways in three major ways, explicitly: sensible to you, easy to memorize, and easily recalled to mind. (Buzan, 2008) confirms that Mind Mapping is a creative note taking strategy in a visualization and graphic form that is used to make people feel easy in entering information into their brain, keeping information in long term memory and taking it out from their brains easily by engaging imagination and association. In addition, they can share their own ideas to complete them in order to make a good writing.

Think Pair Share is one of cooperative learning strategis who was developed by Frank Lyman gives the opportunity to students to do individually and collaboratively with others (Lie, 2007). This study requires students to think about the problem individually, then they discuss their own ideas to the group or paired. Think pair share can promote and support the students' higher order thinking skill. When the students are building their ideas and discuss it with the group. Finally, they share the final thought. It is a kind of strategy that the students become active participants in learning writing in a way to organize thought generate from discussion.

\section{Statement of The Problem}

Based on the background, there is a problem "Is there any significant difference in students' writing ability between the students who are taught writing descriptive text using Mind Mapping strategy with Think Pair Share strategy and those who are not?"

\section{Objective of The Study}

Based on the problem stated above, the objectives of the study is to know whether there is a significant difference in students' writing ability between the students who are taught writing descriptive text using Mind Mapping strategy with Think Pair Share strategy and that of those who are not. 


\section{Methods}

This chapter discusses about the research design, research variable, population and sample, the treatment that consists of the instructional material, the activities, and the teacher, time allocation, the strategy of data collection and data analysis, and research instrument.

This study applied a quasi-experimental study, as (Susan, 2005, p. 148) stated that the quasiexperimental research is a typical of the experimental study without random assignment to define the control group and the experimental group. In the same idea, (Fraenkel ; Wallen, 2007) affirmed quasiexperimental design do not include the use of random in selecting sample of the reseach. Moreover, (Sugiyono, 2017) clarifies quasi-experimental design is used because it is difficult to get the control group. This study appllied non-equivalent control group design.

This study consisted of two kind of groups; they were experimental group and control group. The different treatment were applied to the two-groups. Teaching writing descriptive text using mind mapping strategy with think pair share strategy as a treatment will be applied to the experimental group. On the other hand, the control group will be taught writing descriptive text using conventional method or currently used in teaching writing. However, both of the groups were taught the same materials based on the curriculum.

The pre test and post test were administered not only to the experimental group but also the control group. The pre test is as starting point to verify the condition of both groups. Finally, at the end of the treatment, the experimental group and the control group received a post test; the result of the post test was to define the significance difference between the experimental group and the control group. This research applied two classes of the tenth graders of SMKN 1 Pungging. They were X TKJ1 as experimental group and X TKJ 2 as control group for applying teaching writing descriptive text using mind mapping with think pair share.

This study had two main variables; there are one independent variable $(\mathrm{X})$ and two dependent variables $\left(Y_{1}\right.$ and $\left.Y_{2}\right)$. The independent variable that presumed to influence the dependent ones is teaching writing with mind mapping with think pair share. Finally, the dependent variable was variable that simply measured by the researcher was the students' ability in writing descriptive text.

This research uses a series of test and scoring scale as instruments. The researcher also utilizes the scoring rubric as (Brown H. D., 2004) suggests that there are five parts should be scored in writing as analytic scale for descriptive writing as follows:

Table 1. Scoring Rubric of writing descriptive text. Adapted from Brown 2004

\begin{tabular}{|c|c|c|}
\hline Aspect & Score & Performance \\
\hline $\begin{array}{l}\text { Content }(\mathrm{C}) \\
30\end{array}$ & $22.5-30$ & $\begin{array}{l}\text { The topic is complete and clear } \\
\text { and the details are relating to the topics }\end{array}$ \\
\hline \multirow[t]{3}{*}{$\begin{array}{ll}- & \text { Topic } \\
- & \text { Detail }\end{array}$} & $15-22.5$ & $\begin{array}{l}\text { The topic is complete and clear but } \\
\text { the details are almost relating to the topic }\end{array}$ \\
\hline & $7.5-15$ & $\begin{array}{l}\text { The topic is almost complete and } \\
\text { clear but the details are not relating to } \\
\text { the topic }\end{array}$ \\
\hline & $1-7.5$ & $\begin{array}{l}\text { The topic is not clear and the } \\
\text { details are not relating to the topic }\end{array}$ \\
\hline \multirow{5}{*}{$\begin{array}{ll} & \text { Organization }(\mathrm{O}) \\
20 & \\
- & \text { Identification } \\
- & \text { Description }\end{array}$} & $15-20$ & $\begin{array}{l}\text { Identification is almost complete } \\
\text { and descriptions are arranged with } \\
\text { proper cohesive devices }\end{array}$ \\
\hline & $10-15$ & $\begin{array}{l}\text { Identification is almost complete } \\
\text { and descriptions are arranged with } \\
\text { almost }\end{array}$ \\
\hline & & proper cohesive devices \\
\hline & $5-10$ & $\begin{array}{l}\text { Identification is not complete and } \\
\text { descriptions are arranged with few } \\
\text { misuse cohesive devices }\end{array}$ \\
\hline & $1-5$ & $\begin{array}{l}\text { Identification is not complete and } \\
\text { descriptions are arranged with misuse } \\
\text { cohesive devices }\end{array}$ \\
\hline Grammar (G) & $15-20$ & $\begin{array}{llll}\text { Very } & \text { few } & \text { grammatical } & \text { or } \\
\end{array}$ \\
\hline
\end{tabular}




\begin{tabular}{|c|c|c|}
\hline Aspect & Score & Performance \\
\hline \multirow{4}{*}{$\begin{array}{ll} & 20 \\
- & \text { Simple present tense } \\
- & \text { Adjective order }\end{array}$} & \multicolumn{2}{|r|}{ agreement errors } \\
\hline & $10-15$ & $\begin{array}{l}\text { Few grammatical or agreement } \\
\text { errors but not influence the meaning }\end{array}$ \\
\hline & $5-10$ & Numerous grammatical errors \\
\hline & $1-5$ & $\begin{array}{ccc}\text { Frequent } & \text { grammatical } & \text { or } \\
\text { agreement errors. } & & \\
\end{array}$ \\
\hline \multirow{4}{*}{$\begin{array}{l}\text { Style and } \\
\text { expression (SE) } \\
20\end{array}$} & $15-20$ & $\begin{array}{l}\text { Precise vocabulary usage; use of } \\
\text { parallel structures; concise }\end{array}$ \\
\hline & $10-15$ & $\begin{array}{l}\text { Attempt variety; good vocabulary; } \\
\text { style fairly concise }\end{array}$ \\
\hline & $5-10$ & $\begin{array}{l}\text { Some vocabulary misused; lacks } \\
\text { awareness of register }\end{array}$ \\
\hline & $1-5$ & $\begin{array}{l}\text { Inappropriate use of vocabulary; } \\
\text { no concept of sentence variety }\end{array}$ \\
\hline \multirow{5}{*}{$\begin{array}{ll} & \text { Mechanics (M) } \\
& 10 \\
- & \text { Spelling } \\
- & \text { Punctuation } \\
- & \text { Capitalization }\end{array}$} & $7.5-10$ & $\begin{array}{llll}\text { It } & \text { uses } & \text { correct } & \text { spelling, }\end{array}$ \\
\hline & & punctuation and capitalization \\
\hline & $5-7.5$ & $\begin{array}{l}\text { It has occasional spelling, } \\
\text { punctuation and capitalization errors }\end{array}$ \\
\hline & $2.5-5$ & $\begin{array}{l}\text { It has frequent errors of spelling, } \\
\text { punctuation and capitalization }\end{array}$ \\
\hline & $1-2.5$ & $\begin{array}{l}\text { It is ignore of spelling, punctuation } \\
\text { and capitalization }\end{array}$ \\
\hline
\end{tabular}

Source: Silabus Bahasa Inggris SMK

\section{Strategy of Data Collection}

The set of writing test only consisted of one test item. It is used to collect data related to the students' improvements after the treatment is given to both groups. Before the instrument is used in the real test, there was a try-out on the instrument. The aim of conducting the try-out test is to get information dealing with the characteristics of the test. (Best, 1981) indicates that a good test must have several features; two of them are validity and reliability. Since the test item is in the form of a single instruction, the try out was done to note the readability. The try out was done by asking a group of students who are not the subjects of the research; and the test item is readable since most of them state that it can be understood and they can execute the test based on the test item.

The test item is for the trying out is : Write down a descriptive text about your own cell phone.

In collecting the data, the researcher will use the test. Test was used to collect the data on students' writing ability of descriptive text of Mind Map with think pair share and conventional method in teaching writing.

\section{Pre-test}

The pre test is administered before the treatment to both of the groups in research.

Post test

The post test is administered after the treatment to both of the groups.

\section{Data Analysis}

The data will be analyzed using t-test. It is used to answer the research questions by using SPSS 20 Statistic. The data of this study is score, therefore the researcher administered the pre-test and post-test of both experimental and control group.

$T$-test is analyzed using SPSS 20 to investigate whether a difference between the means of two samples is significant. Researcher will check the $t$ in a statistical table to determine the level of significant that has been reached. The .05 level of significant is the indicator that there is significant difference between two groups.

The result criteria are described as follows;

- If $t_{0} \leq \mathrm{t}$-table, $H_{0}$ is accepted. It can be said that there is no significant difference of using Mind Map with Think Pair share to improve students' ability in writing descriptive texts.

If $t_{0} \geq \mathrm{t}$-table, $H_{a}$ is accepted. It can be said there is significant difference of the students' ability in improving writing descriptive texts using Mind Map with Think Pair Share. 


\section{Treatment}

Instructional Writing Material

(Richards and Renandya, 2002) proposes seven features in selecting writing textbook, namely; topics, types of writing, opportunities for and instruction in methods of generating ideas, instruction on principle rhetorical organization, opportunities for collaboration, opportunities for revision, and instruction in editing and proofreading.

\section{The Teaching Procedures}

There are two main situations in this research. First of all is teaching writing descriptive text using mind mapping with think pair share will be applied in the X TKJ1 as the experimental group. Besides, the teaching writing descriptive text using conventional method will be applied in X TKJ2 as the control group.

\section{Result and Discussion}

The finding is obtained from the analysis of the data collected after experiment accomplished to the tenth graders of SMK Negeri 1 Pungging Mojokerto. There were two kinds of instruments used to collect the data of this study such as pre-test and post-test. The results from this study were obtained from the data from the pre-tests and the post-tests

The score based on the descriptive rubric. Furthermore, the researcher employed two different raters to score the test and took the average for each rater. The purpose of two raters is to avoid the unfair in giving the score. After getting the data from the pre-test, the students were given the treatments to implement the Mind Mapping with Think Pair Share strategy for teaching writing of a descriptive text for $\mathrm{X}$ TKJ 1 To complete the data, the writer then conducted the post-test session to get the final scores for the students for their writing of a descriptive text for X TKJ 1 after the Mind Mapping with Think Pair Share strategy had been implemented.

The data were taken from the score of pre-test and post-test from all the groups. Therefore, each group had two scores pre-test and post-test score. According to the result of computation, the mean and the standard deviation of both experimental and control groups can be presented in the following table:

Table 2. Descriptive Statistics

\begin{tabular}{|c|c|c|c|c|c|c|}
\hline \multirow{6}{*}{ 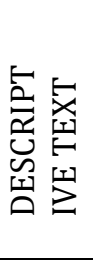 } & Group & $\mathrm{N}$ & Mini-mum & Maxi-mum & Mean & Std Devia-tion \\
\hline & Pre test Experi-ment & 32 & 50 & 75 & 86.28 & 8.056 \\
\hline & Post test experi-ment & 32 & 78 & 90 & 80.18 & 3.401 \\
\hline & Pre test Control & 32 & 50 & 71 & 56.95 & 6.040 \\
\hline & Post test Control & 32 & 50 & 73 & 58.44 & 6.107 \\
\hline & Valid N (list wise) & 32 & & & & \\
\hline
\end{tabular}

Based on the table above, it is noticed that the mean of post test of the experimental group is increased 6.10 point. It means that there is an influence of the teaching writing descriptive text by using mind mapping with think pair share.

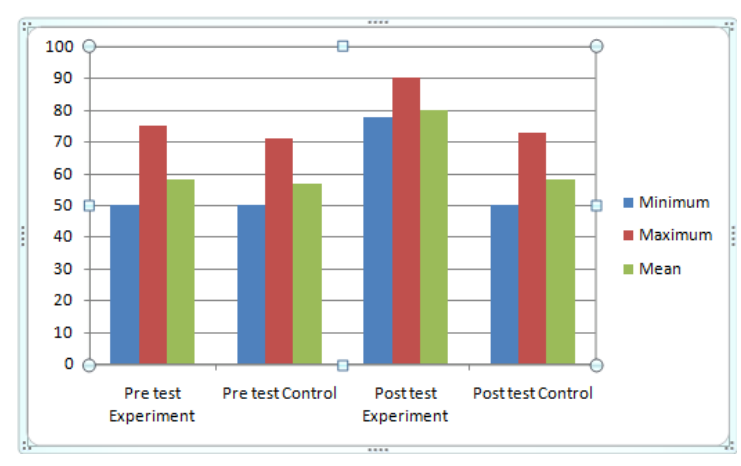

Figure 1. Writing Descriptive Text Achievement of Both Experimental and Control Groups 
The figure 1. above presents that the mean of the experiment group increased significantly. On the other hands, the control group is approximately the same between pre test and post test. It means that the teaching writing descriptive text using Mind Mapping with Think Pair Share gives positive impact to the students' writing achievement.

Table 3. The Mean and Standard Deviation of Pre-Test and Post Test of Experimental and Control group in Descriptive Text.

\begin{tabular}{|c|c|c|c|c|c|c|c|}
\hline \multirow{2}{*}{ Group } & \multirow{2}{*}{$\mathrm{N}$} & \multicolumn{2}{|l|}{ Mean } & \multicolumn{2}{|c|}{ Standard Deviation } & \multirow{2}{*}{$\begin{array}{l}\text { Std } \\
\text { mean }\end{array}$} & \multirow[t]{2}{*}{ Error } \\
\hline & & Pre-Test & Post-Test & Pre-Test & Pos-Test & & \\
\hline Experi-mental & 32 & 58.28 & 80.16 & 8.056 & 3.401 & 1.424 & \\
\hline Con-trol & 32 & 56.95 & 58.44 & 6.040 & 6.107 & 1.068 & \\
\hline
\end{tabular}

Using the information displayed in the table 3.2 , the pre-test score is used as a starting point to compare with the post-test. It became the basis of the use t-test to analyze the data to compare between the experimental and control group, the statistical computation was done using t-test as well. The result calculated by SPSS 20.0; it is a computer program statistical calculation and the result is further discussed in Hypothesis Testing. From the table above, it can be analyze that the mean of post-test of experimental group is increased from 58.28 to 80.16 . It can be noticed that the mean of the post-test of experimental is 21.72 higher than the mean of post-test of control group.

Hypothesis Testing

Hypothesis testing was done to find out whether the null hypotheses have to be rejected or accepted. In this study the null hypothesis is "there is no significant difference between students' ability in writing descriptive text with using Mind Map with Think Pair Share and conventional method at the tenth grade of SMKN 1 Pungging." The students of experimental group achieve higher score if result of t-test is higher than the table on the level significance 0,05 or $5 \%$. To test the null hypothesis, the t-test computed using SPSS 2.0 that is a kind of computer program used in statistical issue. Finally, its result could be presented in the following table:

Table 4. The Result of t-test Descriptive Text

\begin{tabular}{lccllllll}
\hline \multirow{2}{*}{ Gro-up } & \multirow{2}{*}{ N } & df & Mean & & \multicolumn{2}{l}{ Standard Deviation } & \multirow{2}{*}{ tva-lue } & \multirow{2}{*}{ t.05 } \\
\hline Ex-peri-men-tal & 32 & 31 & 58.28 & 80.16 & 8.056 & 3.401 & \multirow{2}{*}{133.31} & \multirow{2}{*}{3.633} \\
Con-trol & 32 & 31 & 56.95 & 58.44 & 6.040 & 6.107 & & Source: SPSS 20
\end{tabular}

The number of students who took the experiment continuously present during to the research. They are 32 students for each group.

Referring to the table 3.3 that the result of pre-test and post test in teaching writing descriptive text through mind mapping with think pair share shows that the $t$-value of showed 133.31and the $t$-table is 3.633 with level of significance 5\%. It indicates that the null hypothesis that there is no significant difference between students' ability in writing descriptive by using Mind Map with Think Pair Share at the tenth grade of SMKN 1 Pungging is rejected. Consequently, the use of Mind Mapping with Think Pair Share in teaching writing descriptive text is give positive influence to the students' writing ability.

The result proves that the use of Mind Mapping with Think Pair Share in teaching writing descriptive text can help students to achieve higher score. Besides, it proved that the Mind Mapping with Think Pair Share technique contributes to help students' writing ability in writing Descriptive texts in terms of enriching vocabularies, improving creativity, arranging sentences and organizing ideas. Nevertheless, mind mapping has disadvantages too. The Mind Mapping with Think Pair Share technique has been considered somewhat time consuming. This is relevant to the finding of ( Buzan, 2008).

Students assumed that they need a long time to make a mind mapping, especially for students who have difficulties to draw. The students usually focused more only to make a good mind map with good picture and harmonized colors without estimated time to make a good writing product. Moreover, students need more time because they still have to open the dictionary to make a list of keyword and 
sometimes confused to determine the categorization in every branch. Furthermore, applying this technique is quite new for the students.

Teaching writing with mind mapping with Think Pair Share helps students to organize their ideas more effectively and release their anxiety that cause the writer's block. By using the technique, the students could feel at ease in performing the writing tasks.

\section{Conclusion}

The Mind mapping with Think Pair Share technique is an effective teaching technique for teaching writing descriptive text to the tenth grade students of SMK Negeri 1 Pungging Mojokerto. Since Mind mapping with Think Pair Share technique is simple, fun, and arousing students' creativity in generating and organizing their ideas, students are getting more active and more encouraged to study writing and improved their writing skills. As a result, the students' writing achievement is improved optimally. Implication many students find writing difficult, and they find getting started the most difficult part of writing. Mind mapping with Think Pair Share technique reduces the difficulty by giving students an organizing strategy to get them started. Mind mapping with Think Pair Share technique, ideas are freely associated and written out without pressure, thereby reducing tension and resistance often associated with writing. Although, it is one type of outlining methods, the product of the prewriting activity using Mind mapping with Think Pair Share technique is notably different from the one using other type of outlining. Unlike conventional outlining, the product of prewriting activity using Mind mapping with Think Pair Share technique does not follow a rigid fixed linear. In outlining, ideas must be arranged sequentially which is contradictory with the natural way of how brain works, because brain works in a non linear way. The elements of a given mind map are arranged intuitively according to the importance of the concepts, and are classified into groupings, branches, or areas, with the goal of representing semantic or other connections. Mind mapping with Think Pair Share technique help students to organize the ideas more effectively and release their anxiety that cause the writer's block. By using the technique, the students could feel at ease in performing the writing task because they do their task collaboratively.

It is the correct choice of teaching technique can make the teaching and learning process not only run well but also interesting and enjoyable. Enjoyable teaching and learning activities will help students receive the material more effectively and efficiently; it will also makes the teacher more focus on the necessary things needed for the class. The Mind mapping with Think Pair Share technique is technique which will lead students to be more cooperative; thus it is good to be applied in small classes as well as the big ones. It is simple, fun and arousing creativity. For the students using Mind mapping with Think Pair Share technique is a simple technique which can be used for writing activities. Using Mind mapping with Think Pair Share technique is also useful in other writing activities to generate and organize ideas, opinion and thoughts. So, the researcher suggests that all students learn how to use it. Mind mapping with Think Pair Share not only can be applied in writing but also the other skill, such as: speaking, reading, and listening. The technique is suitable to develop students' writing at any education level. It also promotes higher order thinking skill when the students discuss their own ideas to their group. Finally, for the future researchers a similar research with different population characteristic is also promising a replication of this research design using Mind mapping with Think Pair Share technique as teaching technique as the treatment for teaching writing can be done with some alteration. It is possibly also useful to have research with different students' condition like students' habit, motivation, or interest.

\section{Reference}

Best, J. (1981). Research in Education. Prentice Hall,Inc.

Brown, H. D. (2001). Teaching by Principle (Second ed.). New York: A Pearson Wducation Company.

Brown, H. D. (2004). Language Assesment Principle and Classroom Practice. New York: Longman pearson education.

Buzan, T. (2012). How to Mind Map. Mind Map untuk meningkatkan Kreativitas . Jakarta: Gramedia Pustaka Utama.

Buzan, T. (2008). How To Mind Map: Mind Map untuk meningkatkan kreativitas. Jakarta: Gramedia Pustaka Utama. 
Jack R. Fraenkel ; Norman F. Wallen. (2007). How to design and Evaluate Research in education. New York: Mc Graw-Hill.

Kemendikbud. (2016). Silabus Mata Pelajaran Sekolah Menengah Atas/Madrasah Aliyah/Sekolah Menegah Kejuruan/Madrasah Aliyah Kejuruan SMA/MA/SMK/MAK. Jakarta.

Lie, A. (2007). Cooperative Learning. Jakarta: Gramedia.

Nunan, D. (1991). Language Teaching Methodology. New York: Prentice Hall.

Raimes, A. (1993). Technique in Teaching writing. New York: Oxford University Press.

Richards and Renandya. (2002). Methodology in language teaching. cambridge University Press.

Rustler, F. (2012). Mind Mapping For Dummies. (T. Buzan, Ed.) A Jogn Wiley and son, Ltd.

Sugiyono. (2017). Metode Penelitian Kuantitatif Kualitatif dan R\&D. Bandung: Alfbeta.

Susan, A. a. (2005). Second Language Research Methodology and Design. New Jersey: Lawrence Erlbaum Assosiation.

Ur, P. (2003). A course in Language Teaching Practice and Theory. Tranee book. (M. W. Wright, Ed.) Cambridge University Press. 